\title{
Determination of ochratoxin A levels in ivorian cocoa beans intended for exportation
}

\author{
Adama COULIBALY ${ }^{1,2}$, Ardjouma DEMBELE ${ }^{1}$, Henri Marius Godi BIEGO ${ }^{2 *}$, \\ Kouassi Maxime BOHOUSSOU² and Abba TOURE ${ }^{3}$ \\ ${ }^{1}$ Central Laboratory of Agrochemistry and Ecotoxicology, LANADA 04 BP612 Abidjan 04, Côte d'Ivoire. \\ ${ }^{2}$ Laboratory of Biochemistry and Food Science, Faculty of Biosciences, University of Cocody-Abidjan, \\ 22 BP 582 Abidjan 22, Côte d'Ivoire. \\ ${ }^{3}$ Environment and Health Department, Institute Pasteur, BP V 34 Abidjan, Côte d'Ivoire. \\ *Corresponding author; E-mail: biegoh3@yahoo.fr; (225) 07018836
}

\begin{abstract}
The objective of this study is to monitor levels of ochratoxin A (OTA) in terms of the marketability of Ivorian cocoa beans stored at the ports of Abidjan and San Pedro. Thus, 270 samples of cocoa beans were analyzed. Merchantability and OTA levels were determined respectively according to the Ivorian Coffee and Cocoa stock exchange standards and the European Community regulation related to the analytical methods for the control of mycotoxins levels in foodstuffs. As regards merchantability, a significant difference at $5 \%$ risk was revealed between the values of moisture, graining and grades. Arithmetic means for humidity were respectively $6.7 \%$ and $6.5 \%$ for samples from the ports of Abidjan and San Pedro. The number of beans per $100 \mathrm{~g}$ of cocoa beans was 94 and 97 respectively for samples from ports of Abidjan and San Pedro. The classification in grades in terms of marketability indicates that respectively $87 \%$ and $89 \%$ of batches collected at ports of Abidjan and San Pedro can be marketed. Pertaining to OTA, no significant difference at 5\% risk has been revealed between the concentrations found in samples from both ports and between different grades. OTA concentrations obtained averaged out at respectively $0.87 \mu \mathrm{g} / \mathrm{kg}$ and $0.94 \mu \mathrm{g} / \mathrm{kg}$ of cocoa beans for Abidjan and San Pedro. Merchantability criteria and OTA levels in cocoa beans were loosely linked in view of flimsy values of squared correlation coefficients.

(C) 2012 International Formulae Group. All rights reserved.
\end{abstract}

Keywords: Ochratoxin A, cocoa bean, correlation, merchantability.

\section{INTRODUCTION}

Stakeholders in the cocoa sector agree that it is of particular interest that cocoa farmers apply good agricultural practices to warrant cocoa beans of prime quality. Cocoa beans are prone to quite a few post-harvest treatments that can be summarized in a pod breaking, fermentation, drying, packaging and storage before marketing. When these treatments are poorly conducted, that leads inevitably to the appearance of flaws in the beans and, most worrying, the dissemination of toxin-producing molds such as Aspergillus responsible for the production of ochratoxin A (Bastide et al., 2006; Sackou et al., 2007). These defects (moldy, slaty, moth-eaten, germinated, flat, and high moisture levels) usually spring from attacks by insects or 
improper weather conditions (Bastide et al., 2006; Cocoqual, 2007; Pauline et al., 2008).

To ensure the marketability of cocoa for export, the Ivorian Coffee and Cocoa stock exchange has enacted rigid standards. Every consignment of cocoa which does not meet these rigorous standards is prohibited from leaving the country (BCC, 2009).

Several previous studies have pointed out the presence of ochratoxin A in cocoa and diverse byproducts (Miraglia and Brera, 2002; Burdaspal and Legarda, 2003; Bonvehi, 2004; Tafuri et al., 2004; Matsuoka, 2006). In Côte d'Ivoire, this mycotoxin (OTA) has been found in cocoa from both production areas and Ivorian ports (Laine, 2001; Dembele et al., 2009). We therefore undertook this study to assess the levels of ochratoxin A based on criteria of the marketability of cocoa beans for exportation.

\section{MATERIALS AND METHODS Sampling}

The plant material used in this study consisted of cocoa beans collected from November 2007 to March 2008 at the ports of Abidjan (120 samples) and San Pedro (150 samples) according to the European Community regulation (EC, 2006).

\section{Determination of cocoa beans marketability}

According to Ivorian regulation (BCC, 2009), three parameters are taken into account when it comes to assess the merchantability of cocoa beans: the moisture content, the graining and the classification in grades (Table 1). The moisture content of cocoa beans was determined with the help of an oven at $105{ }^{\circ} \mathrm{C}$ until constant weight (AOAC, 1990). The graining was determined by counting the number of beans in $100 \mathrm{~g}$ of whole cocoa beans free of any foreign materials. Finally, the classification in grades was related to the percentage of defective cocoa beans for $100 \mathrm{~g}$ of whole cocoa beans. To this end, $100 \mathrm{~g}$ of whole cocoa beans were cut lengthwise through the middle with a bean knife brand STANLEY, to expose a maximum cut surface of cotyledons. Visual examination of the inner of the two half-beans highlights possible flaws (ISO, 1977; Hamid and Lopez, 2000).

\section{Determination of OTA levels in cocoa beans \\ Extraction of OTA}

The entire sample was crushed in a hammer mill to obtain a homogeneous fine grind. In a Nalgene jar containing $15 \mathrm{~g}$ of homogenate, $150 \mathrm{~mL}$ of aqueous methanolbicarbonate $1 \%(\mathrm{v} / \mathrm{v}, 50: 50)$ were added. The mixture was homogenized by Ultra-Turax for 3 minutes and the homogenate was centrifuged at $5000 \mathrm{rpm}$ for 5 minutes at $4{ }^{\circ} \mathrm{C}$. The supernatant was filtered through filter paper into tubes of $25 \mathrm{~mL}$. To $11 \mathrm{~mL}$ of filtrate were added $11 \mathrm{ml}$ of saline phosphate buffered (PBS) at $\mathrm{pH}$ 7.3. Immunoaffinity columns brand Ochraprep and R-Biopharm were conditioned with $10 \mathrm{~mL}$ of PBS. Purification of $20 \mathrm{~mL}$ of the mixture was made on immunoaffinity columns and OTA extraction was performed with two volumes of $1.5 \mathrm{~mL}$ of PBS at a flow rate of 5 $\mathrm{mL} /$ minute. The resulting sample was packed in a chromatographic tube and the analysis of OTA was made by HPLC using the European community regulation (EC, 2006).

Apparatus

A liquid chromatograph HPLC brand Shimadzu coupled to a fluorescence detector was used and the operating conditions are described in Table 2.

\section{Statistical analysis}

The averages were calculated with their standard deviations to assess OTA levels, moisture content, graining and grades of cocoa beans. The squared coefficient of Bravais-Pearson was calculated to assess the correlation between OTA and the criteria for marketability. The homogeneity of means (OTA, moisture content and graining) was determined by a one or two-way analysis of variance (sampling location or period and/or grade) through Fisher test, using SPSS 12 software at $5 \%$ risk. 
Table 1: Cocoa beans merchantability standard in Côte d'Ivoire.

\begin{tabular}{|c|c|c|c|}
\hline \multicolumn{4}{|c|}{ Moisture content } \\
\hline Maximum value & owed & & $8 \%$ \\
\hline \multicolumn{4}{|c|}{ Number of beans per $100 \mathrm{~g}$ of cocoa beans } \\
\hline Maximum value & & & 105 \\
\hline \multicolumn{4}{|c|}{ Grades } \\
\hline \multirow{2}{*}{ Grade } & \multirow{2}{*}{ Moldy } & \multirow{2}{*}{ Slaty } & Defective \\
\hline & & & Moth + Germinated + Flat \\
\hline Grade I (GI) & $\leq 3 \%$ & $\leq 3 \%$ & $\leq 3 \%$ \\
\hline Grade II (GII) & $>3 \%$ and $\leq 4 \%$ & $3 \%$ and $\leq 8 \%$ & $>3 \%$ and $\leq 6 \%$ \\
\hline Low grade $(\mathrm{LG})$ & $>4 \%$ & $>8 \%$ & $>6 \%$ \\
\hline
\end{tabular}

Table 2: HPLC analytical conditions.

\begin{tabular}{lc}
\hline Precolumn & Shim-pack GVP-ODS $10 \times 4.6 \mathrm{~mm}$ \\
Column & Shim-pack GVP-ODS $250 \mathrm{~mm} \times 4.6 \mathrm{~mm}$ \\
Detector & Flurescence, $\lambda$ excitation: $330 \mathrm{~nm}, \lambda$ emission: $460 \mathrm{~nm}$ \\
Mobile phase & Acetonitrile/Water/Acetic acid $(99 / 99 / 2)$ \\
Injected volume & $100 \mu \mathrm{L}$ \\
Flow rate & $1 \mathrm{~mL} /$ minute \\
Column temperature & $40^{\circ} \mathrm{C}$ \\
Rinsing solvent & Acetonitrile \\
Analysis duration & 12 minutes \\
\hline
\end{tabular}

\section{RESULTS}

\section{Merchantability of cocoa beans}

The results of the marketability of cocoa beans are shown in Table 3. The average moisture contents were respectively $6.7 \%$ and $6.5 \%$ for the ports of Abidjan and San Pedro and $6.6 \%$ for all samples combined. The ports of Abidjan and San Pedro present respectively $7 \%$ and $1 \%$ of samples analyzed with a moisture content above the limit value of $8 \%$ set by Ivoirian regulation (BCC, 2009). Results for graining indicated 94 and 97 beans per $100 \mathrm{~g}$ of cocoa beans for samples from the ports of Abidjan and San Pedro, which corresponds to 96 beans for both ports combined. The homogeneity of means between moisture contents and graining values performed by a one-way analysis of variance (sampling site), through Fischer-test revealed a significant difference at 5\% risk. The classification in grades revealed that $87 \%$ and $89 \%$ of samples coming respectively from the ports of Abidjan and San Pedro can be exported (Table 3 ).

\section{Ochratoxin A levels in cocoa beans}

Table 4 presents average values and ranges for OTA levels found in all samples from the ports of Abidjan and San Pedro. OTA average concentrations were respectively of $0.87 \mu \mathrm{g} / \mathrm{kg}$ and $0.94 \mu \mathrm{g} / \mathrm{kg}$ for samples collected in Abidjan and San Pedro that is $0.91 \mu \mathrm{g} / \mathrm{kg}$ for both ports combined. OTA concentrations ranged between 0.05 and $4.79 \mu \mathrm{g} / \mathrm{kg}$ for samples from Abidjan and 0.05 and $9.10 \mu \mathrm{g} / \mathrm{kg}$ for those from San Pedro. The homogeneity of OTA concentrations which was performed by a one-way analysis of variance (sampling site), through Fischer test did not reveal a significant difference ( $p$ $<0.05)$ as shown in Table 4. Combined data from both ports showed $13 \%$ of samples with OTA concentrations exceeding the maximum limit value of $2 \mu \mathrm{g} / \mathrm{kg}$ set by the European Union. 
OTA levels in terms of cocoa beans grades

OTA levels in terms of cocoa beans grades are presented in Table 5. Grade I cocoa beans have average OTA levels respectively of $0.94 \mu \mathrm{g} / \mathrm{kg}$ and $0.89 \mu \mathrm{g} / \mathrm{kg}$ in the ports of Abidjan and San Pedro. Those classified Grade II have average OTA levels respectively of $0.80 \mu \mathrm{g} / \mathrm{kg}$ and $1.02 \mu \mathrm{g} / \mathrm{kg}$ in the ports of Abidjan and San Pedro. Lowgrade cocoa beans presented on average 0.80 $\mu \mathrm{g} / \mathrm{kg}$ and $0.95 \mu \mathrm{g} / \mathrm{kg}$ respectively in Abidjan and San Pedro. The homogeneity of the concentrations of OTA implemented by a two-way analysis of variance (Sampling site and grade) through Fischer-test did not reveal a significant difference $\mathrm{p}<5 \%$ as shown in Table 5.

Assessment of the variation of
marketability criteria and OTA levels
We have monitored the variation of
marketability criteria as well as OTA levels
during a time period of 6 months (Table 6 ).
OTA average concentrations ranged from 0.54
$\mu \mathrm{g} / \mathrm{kg}$ to $1.11 \mu \mathrm{g} / \mathrm{kg}$, moisture content ranged
between $6.5 \%$ and $6.8 \%$, and the number of beans for $100 \mathrm{~g}$ of cocoa beans between 95 and 97 beans per $100 \mathrm{~g}$. As for the grades, Grade I ranged from $3 \%$ to $51 \%$, Grade II from $8 \%$ to $31 \%$ and the Low grade from $0 \%$ to $55 \%$.

The homogeneity of OTA levels, moisture content and graining performed by a one-way analysis of variance (sampling period), through F-test, revealed for some criteria a significant difference at $\mathrm{p}<5 \%$ (Table 6).

\section{Correlation between OTA levels and cocoa beans marketability criteria}

The correlation between merchantbility criteria is very low except for the correlation between sprouted beans and flat ones $(\mathrm{R} 2=0.145)$ and to a certain extent between moldy beans and sprouted ones $(\mathrm{R} 2=$ 0.052). The correlation between merchantability criteria and OTA levels is also weak. The tightest correlation was between OTA levels and the number of beans for $100 \mathrm{~g}$ of cocoa beans (Table 7).

Table 3: Marketability results.

\begin{tabular}{|c|c|c|c|c|}
\hline \multicolumn{5}{|c|}{ Moisture content (\%) } \\
\hline Sampling sites & Average & Range & \multicolumn{2}{|c|}{$\begin{array}{c}\text { Percentage of sample* }(\%) \\
\text { Moisture } \geq 8 \%\end{array}$} \\
\hline Abidjan & $6.7 \pm 0.7 \mathrm{a}$ & $5.6-9.9$ & \multicolumn{2}{|r|}{7.0} \\
\hline San Pedro & $6.5 \pm 0.5 b$ & $5.4-9.0$ & \multicolumn{2}{|r|}{1.0} \\
\hline Both ports & $6.6 \pm 0.6 \mathrm{ab}$ & $5.4-9.9$ & \multicolumn{2}{|r|}{4.0} \\
\hline \multicolumn{5}{|c|}{ Graining (Number of beans for $100 \mathrm{~g}$ of cocoa beans) } \\
\hline Sampling sites & Average & Range & \multicolumn{2}{|c|}{$\begin{array}{c}\text { Percentage of sample* }(\%) \\
\text { Graining } \geq 8 \%\end{array}$} \\
\hline Abidjan & $94 \pm 5 \mathrm{a}$ & $75-105$ & \multicolumn{2}{|r|}{0.0} \\
\hline San Pedro & $97 \pm 5 b$ & $81-115$ & \multicolumn{2}{|r|}{5.0} \\
\hline Both ports & $96 \pm 6 c$ & $75-115$ & \multicolumn{2}{|r|}{3.0} \\
\hline \multicolumn{5}{|c|}{ Classification in grades $(\%)$} \\
\hline Sampling sites & Grade I (GI) & Grade II (GII) & Low-grade (LG) & Exportables (GI+GII) \\
\hline Abidjan & 48 & 39 & 13 & 87 \\
\hline San Pedro & 57 & 32 & 11 & 89 \\
\hline Both ports & 53 & 36 & 11 & 89 \\
\hline
\end{tabular}


Table 4: OTA concentrations in Ivory Coast cocoa beans.

\begin{tabular}{lcccc}
\hline \multirow{2}{*}{ Ports } & \multicolumn{2}{c}{ Ota concentration $(\boldsymbol{\mu g} / \mathbf{k g})$} & \multicolumn{2}{c}{ Percentage of sample } \\
\cline { 2 - 5 } & Average & Range & with OTA level > $\mathbf{~} \mathbf{~ g} / \mathbf{k g}$ \\
\hline Abidjan & $0.87 \pm 0.81 \mathrm{a}$ & $0.05-4.79$ & \multicolumn{2}{c}{$11 \%$} \\
San pedro & $0.94 \pm 0.92 \mathrm{a}$ & $0.05-9.10$ & \multicolumn{2}{c}{$15 \%$} \\
Both ports & $0.91 \pm 0.90 \mathrm{a}$ & $0.05-9.10$ & \multicolumn{2}{c}{$13 \%$} \\
\hline \multicolumn{1}{c}{ The averages } & in a given column & followed by the same letter are not significantly different \\
$(\mathrm{p}<0.05)$ & & &
\end{tabular}

Table 5: OTA levels in terms of Ivory Coast cocoa beans grades.Concentration: $\mu \mathrm{g} / \mathrm{kg}$ ).

\begin{tabular}{lccc}
\hline Ports & Grade I (GI) & Grade II (GII) & Low-Grade (LG) \\
\hline Abidjan & $0.94 \pm 0.83 \mathrm{a} \alpha$ & $0.80 \pm 0.95 \mathrm{a} \alpha$ & $0.80 \pm 0.77 \mathrm{a} \alpha$ \\
San pedro & $0.89 \pm 0.87 \mathrm{a} \alpha$ & $1.02 \pm 1.01 \mathrm{a} \alpha$ & $0.95 \pm 0.92 \mathrm{a} \alpha$ \\
Both ports & $0.91 \pm 0.89 \mathrm{a} \alpha$ & $0.91 \pm 0.87 \mathrm{a} \alpha$ & $0.88 \pm 0.79 \mathrm{a} \alpha$ \\
\hline \multicolumn{4}{l}{ Means followed by the same letters do not differ significantly $(\mathrm{p}<0.05)$. } \\
\multicolumn{4}{l}{ The letter a refers to a comparison of sampling sites while the letter $\alpha$ relates to a comparison of grades. }
\end{tabular}

Table 6: Variation of marketability criteria and OTA levels.

\begin{tabular}{lcccccc}
\hline \multirow{2}{*}{ sampling period } & OTA level & Moisture & Graining & Grade I & $\begin{array}{c}\text { Grade } \\
\text { II }\end{array}$ & $\begin{array}{c}\text { Low- } \\
\text { Grade }\end{array}$ \\
\cline { 2 - 7 } & $(\boldsymbol{\mu g} / \mathbf{k g})$ & $(\boldsymbol{\%})$ & $\begin{array}{c}(\text { Number of } \\
\text { beans })\end{array}$ & $(\boldsymbol{\%})$ & $(\boldsymbol{\%})$ & $(\boldsymbol{\%})$ \\
\hline November & $0.93 \pm 0.90 \mathrm{ab}$ & $6.8 \pm 0.6 \mathrm{a}$ & $95 \pm 8 \mathrm{a}$ & 26 & 23 & 55 \\
December & $1.11 \pm 1.01 \mathrm{a}$ & $6.5 \pm 0.6 \mathrm{~b}$ & $97 \pm 5 \mathrm{a}$ & 51 & 26 & 7 \\
January & $0.73 \pm 0.69 \mathrm{~b}$ & $6.6 \pm 0.6 \mathrm{ab}$ & $96 \pm 4 \mathrm{a}$ & 15 & 31 & 32 \\
February & $0.61 \pm 0.34 \mathrm{~b}$ & $6.5 \pm 0.4 \mathrm{~b}$ & $96 \pm 4 \mathrm{a}$ & 5 & 12 & 0 \\
March & $0.54 \pm 0.35 \mathrm{~b}$ & $0.5 \pm 0.3 \mathrm{~b}$ & $95 \pm 3 \mathrm{a}$ & 3 & 8 & 6 \\
Total of each grade & & & & 100 & 100 & 100 \\
\hline \multicolumn{2}{l}{ In a given column, the averages followed by the same letter are not significantly different $(\mathrm{p}<0.05)}$. &
\end{tabular}

In a given column, the averages followed by the same letter are not significantly different $(\mathrm{p}<0.05)$.

Table 7: Correlation (R2) between OTA levels and cocoa beans marketability criteria.

\begin{tabular}{lcccccccc}
\hline & OTA & \multirow{2}{*}{$\begin{array}{c}\text { Graining } \\
\text { levels }\end{array}$} & \multirow{2}{*}{ Moisture } & \multicolumn{5}{c}{ GRADES } \\
\cline { 5 - 8 } & & & Moldy & Slaty & Moth-eaten & Flat & Sprouted \\
\hline OTA levels & 1.000 & 0.019 & 0.005 & 0.003 & 0.003 & 0.005 & 0.000 & 0.003 \\
Graining & & 1.000 & 0.008 & 0.001 & 0.004 & 0.027 & 0.005 & 0.025 \\
Moisture & & & 1.000 & 0.002 & 0.000 & 0.000 & 0.006 & 0.007 \\
Moldy & & & 1.000 & 0.002 & 0.000 & 0.008 & 0.052 \\
Slaty & & & & 1.000 & 0.013 & 0.036 & 0.022 \\
Moth-eaten & & & & & 1.000 & 0.000 & 0.023 \\
Flat & & & & & & 1.000 & 0.145 \\
Sprouted & & & & & & & & 1.000 \\
\hline
\end{tabular}




\section{DISCUSSION}

Because of the greatest number of samples analyzed that met the requirements for export, the port of San Pedro turned out to be the port with cocoa beans of high marketability criteria levels. The rendering springing from the combination of marketability results from both ports is ambiguous: Ivorian cocoa beans marketability seems decreasing in comparison with the results of a previous study by Laine (2001), whereas it seems to have been improved compared to the results of Dembele et al. (2009). Indeed, Laine obtained an average moisture content of $7.6 \%$, an average of 88 beans for graining and $93 \%$ of exportable beans, while Dembele et al. (2009) pointed out $63 \%$ of exportable beans for both Ivorian ports. For both ports the same trend is observed in the variation of marketability criteria and OTA levels. OTA levels in this study are relatively lower than the values obtained by Dembele et al. (2009), which were respectively of $0.70 \mu \mathrm{g} / \mathrm{kg}$ and 1.25 $\mu \mathrm{g} / \mathrm{kg}$ for the ports of San Pedro and Abidjan.

The assessment of the variation of marketability criteria and OTA levels revealed that samples collected in December and January had the highest marketability. Moreover, OTA levels were most significant in cocoa beans collected in November and December. Hence, cocoa beans of prime quality are produced from December to January. Data from Dembele et al. (2009) study corroborate this fact. Nevertheless, no strong link was established between a poor marketability and OTA level, namely, a sample of Low Grade is not necessarily a sample with a high OTA level.

\section{Conclusion}

Altogether, this study showed an improvement in the marketability of cocoa beans intended for export. It also pointed out similar OTA levels in cocoa beans from both Ivorian ports (San Pedro and Abidjan). No direct relationship was established between the criteria of merchantability and OTA levels in cocoa beans. Thus, complying with standard marketability criteria does not warrant a low OTA level in cocoa beans. Therefore, this study is interesting in the way that it makes available data on Ivorian cocoa beans marketability and on OTA levels as well. However, it will prove of paramount importance to conduct a similar study in production areas, and of particular interest to devise other criteria incorporating both marketability and sanitary quality of cocoa beans.

\section{REFERENCES}

AOAC. 1990. Official Methods of Analysis. $\left(13^{\text {th }}\right.$ edn). Association of Official Analytical Chemists: Arlington, VA, USA.

Bastide P, Fourny G, Durand N, Petithuguenin P, Guyot B, Gilmour M, Lindblom MX. 2006. Identification of sources of Ochratoxin A during post-harvest cocoa processing: influence of harvest quality and Climatic factors. Report of $15^{\text {th }}$ International Cocoa Research Conference, 1990, San Jose, Costa Rica.

Bonvehi SJ. 2004. Occurrence of ochratoxin A in cocoa and chocolate products. $J$. Agric. Food Chem., 52: 6347-6352.

BCC (Bourse du Café et du Cacao). 2009. Qualité du cacao. www.bcc.ci/normescacao.asp.

Burdaspal PA and Legarda TM. 2003. Ochratoxin A in samples of different types of chocolate and cocoa powder, and Marketed in Spain Fifteen foreign countries. Alimentaria, 347: 143-153.

Cocoqual. 2007. Developing biochemical and molecular markers as indices for improving quality assurance in the primary processing of cocoa in West Africa. Final Report. Analysis of the mycological status of cocoa beans with emphasis on ochratoxigenic fungi. Project No.ICA4-CT-2002-10040. Available at: http://cordis.europa.eu/data/PROJ_FP5.

EC (European Communities). 2006. Règlement portant fixation des modes de prélèvement d'échantillons et des méthodes d'analyse pour le contrôle 
officiel des teneurs en mycotoxines des denrées alimentaires. Règlement $\mathrm{N}^{\circ} 401 / 2006$ du 23 février 2006. Journal Officiel de l'Union Eupéenne 9. 3. 2006, p 23.

Dembele A, Coulibaly A, Traoré SK, Mamadou K, Silue N, Touré A. 2009. Determining the level of contamination of Ochratoxin A (OTA) in cocoa beans for export. Tropicultura, 27: 26-30.

Hamid A, Lopez AS. 2000. Quality and weight changes in cocoa beans stored under two warehouses' conditions in East Malaysia. The Planter, Kuala Lumpur, 76: 619-637.

ISO (International Standard Organization). 1977. Cocoa beans - cut test. International Standard Organization 1114/1977.

Lainé K. 2001. Enquête sur les pratiques culturales dans les cacaoyères en Côte d'Ivoire. Rapport de projet PACCC/ICCO/Industrie sur l'amélioration de la qualité du cacao en Côte d'Ivoire, p 27.

Matsuoka T. 2006. OTA contamination in retail chocolate in Japan in 2005. Report of Standards and Assessment Division, Department of Food Safety, Ministry of
Health, Labour and Welfare, Tokyo, Japan.

Miraglia M, Brera C. 2002. Assessment of dietary intake of ochratoxin A by the population of EU Member States-report of experts participating in Task 3.2.7. In: Reports on Tasks for Scientific Cooperation. Directorate-General Health and Consumer Protection of the European Commission. Available at: http://ec.europa.eu/food/fs/scoop/index_e n.html.

Pauline M, Dominique G, Fontana-Tachon A, Bernard G, Pierre RT, Pierre GJ. 2008. Filamentous Fungi Producing Ochratoxin A during cocoa processing in Cameroon. Int. J. Food. Microbiol., 121: 234-241.

Sackou KJ, Oga SS, N'guessan K, Kouadio KL. 2007. Les déterminants de la traçabilité hygiénique dans la filière cacao en Côte d'Ivoire. Cah. Santé Publ., 6:1726.

Tafuri A, Ferracane R, Ritieni A. 2004. Ochratoxin A in Italian Marketed cocoa products. Food Chem., 88: 487-494. 